International Journal of Agriculture, Environment and Bioresearch

Vol. 4, No. 06; 2019

ISSN: $2456-8643$

\title{
SPATIAL ASSESSMENT OF THE EFFECTS OF LANDUSE CHANGE ON FOREST RESOURCES IN IKOT ABASI LOCAL GOVERNMENT AREA, AKWA IBOM STATE, NIGERIA
}

\author{
Ushie I.A. and Eludoyin O.S. \\ Department of Geography and Environmental Management, University of Port Harcourt, Port Harcourt, Nigeria
}

http://doi.org/10.35410/IJAEB.2019.4457

\begin{abstract}
The study assessed the effect of landuse change on forest resources in Ikot Abasi Local Government Area, Akwa Ibom State, Nigeria. Landsat imageries of 1986, 2000 and 2017 were used for the analysis. The imageries were categorized into different classes using maximum likelihood supervised classification module. Descriptive and inferential statistics were used for the data analysis. Findings showed that thick vegetation has decreased from $142.90 \mathrm{~km} 2$ in 1986 to $20.62 \mathrm{~km} 2$ in 2017 . However, built up area increased from $33.20 \mathrm{~km} 2$ to $159.96 \mathrm{~km} 2$ in 2017. Findings also showed that landuse extent for individual land use/ land cover varied significantly in 1986, 2000 and 2017 at $p<0.05$. The study concluded that landuse change has impact on forest resources in Ikot Abasi LGA. It is recommended that anthropogenic activities currently effecting reduction in the size of forest cover should be controlled; and forest management and conservation strategies should be put in place so that forested areas that need to be protected can be protected and preserved.
\end{abstract}

Keywords: Landuse, Landsat, Forest resources, Ikot Abasi, Nigeria.

\section{INTRODUCTION}

Forest resources are natural ecosystems that render services, products and functions that contribute to humankind and other living organisms' survival while also improving the quality of human life ( $\mathrm{Li}$ et al., 2012). The ecosystem services from forest resources include food production, hydrology adjustment, climate regulation, biodiversity maintenance, gas regulation, waste treatment, erosion control, and entertainment (Mendoza Et al., 2012). The provision of ecosystem services is directly affected by land use (Chen et al., 2010 and Mendoza Et al., 2012). However, because of population and economic growth, urban sprawl, and the quick expansion of industrial and agricultural activities, land use has experienced enormous changes worldwide over the past half century, from forest, grassland, and wetland to arable and building land. These changes have caused natural ecosystems to continuously be altered, destroyed, and diminished (Chen et al., 2011). Conversely, because of the increasingly imbalanced provision of economic and natural ecosystems, the effects of land use changes on forest resources and their economic value have become a focus of concern for scientists, policymakers, and stakeholders over the last decade. Land use refers to the purposes for which humans exploit or immediate actions modifying or converting the land and its resources/covers (Turner et al, 1993; de Sherbinin, 2002; Melese, 2016). In other words, Melese (2016) described as the use which could be grazing, agriculture, urban development, logging, and mining among many others. Land use 
change is the conversion of land use due to human intervention for various purposes, such as for agriculture, settlement, transportation, infrastructure and manufacturing, parks, recreation uses, mining and fishery (Williams, 1994; Turner and Meyer, 1994; Melese, 2016). Thus, different human driving forces mediated by the socio-economic setting and influenced by the existing environmental conditions, lead to an intended land use of an existing land cover through the manipulation of the biophysical conditions of the land.

Many parts of the world have seen drastic deforestation in order to exploit forest resources or to further other economic ends, and have also seen more recent efforts to rehabilitate forests and the resources that they provide (Metz, 2015). Forests provide an array of benefits to human societies above and beyond their pivotal roles as habitat and environmental regulators in natural ecosystems. These benefits are often described as resources that people can draw upon for fuel, lumber, and recreational or commercial purposes. The perception that forests provide resources for people has been a prominent factor in spurring efforts to preserve forests. In spite of this economic value, much forestland is being taken out of forest production, largely due to urban sprawl, which has claimed forested areas that will never be replaced. The level of deterioration of forest resources is a factor of uncoordinated land use policy and other forms of land-use such as agriculture, grazing, industrialization, urbanization and water management leading to formation of deserts, bare surfaces and general environmental degradation (Aigbe, 2012).

Land use/ land cover is an important component in understanding the interactions of the human activities with the environment and thus it is necessary to monitor and detect the changes to maintain a sustainable environment. The evolution of GIS, the Global Positioning System (GPS), and Remote Sensing (RS) technologies has enabled the collection and analysis of field data which can be used for strategic planning, modeling, monitoring and assessment of forest Resources (Sonti, 2015). Following the advances in high resolution Remote Sensing Digital Data and Aerial Photography, mapping of the trends of cover changes have become relevant source of information for understanding land cover pattern changes (Wuder, 2007). In recent time, human activities and social factors are recognized to have a paramount importance for understanding of land use change (LUC) (Geist and Lambin, 2012). Driving forces are generally subdivided into two broad categories: proximate causes and underlying causes. LUC is never static; it constantly changes in response to the dynamic interaction between underlying drivers and proximate causes (Lambin and Geist, 2013). The conceptual understanding of proximate causes and underlying forces has a crucial importance to identifying the causes of LULC changes (Melese, 2016).

Proximate causes are the activities and actions which directly affect land use, e.g. wood extraction or clearing land for agriculture. According to Geist and Lambin (2012; Melese, 2016), proximate (direct) causes are immediate actions of local people in order to fulfill their needs from the use of the land. These causes include agricultural expansion, wood extraction, infrastructure expansion and others that change the physical state of land cover (Metz, 2015). At the proximate level, LUC change may be explained by multiple factors rather than a single variable (Geist and Lambin, 2012). Underlying causes are the fundamental forces that trigger the proximate causes, including demographic pressure, economic policy, technological development, institutional and cultural factors (Vancker et al, 2003; Melese, 2016). 
Underlying driving forces, i.e. including demographic pressure, economic status, technological and institutional factors, influence LUC in combination rather than as single causations. The underlying factors have multi-scale sources. Global factors that influence local agricultural marketing or international tourism can be indirectly responsible. Regional factors like the presence of road, access to market, political turmoil and armed conflict may be a direct source of influence in the decision process of land use. Loss of productivity coupled with population boom may be considered local factors. Thus the proximate causes are only manifestations of the underlying causes. Any intervention, therefore, must be geared towards addressing the underlying causes (Bedru et al., 2016). These two major categories of causes operate at different levels. Proximate causes operate at the local level (individual farms, householders, or communities); on the contrary, the sources of underlying causes are at regional and national levels such as districts, provinces, or countries. Underlying causes are often external and beyond the control of local communities (Lambin et al, 2013). Hence, land use change dynamics is a result of complex interactions between several biophysical and socio-economic conditions which may occur at various temporal and spatial scales (Reid et al, 2010). Therefore, it was based on this background that the present study assessed land use change and its effect on forest resources in Ikot Abasi local government area (LGA), Akwa Ibom State, Nigeria.

\section{MATERIALS AND METHODS}

\section{Study Area}

The study was carried out in Ikot Abasi LGA of Akwa Ibom State, Nigeria. Ikot Abasi is located in the south west corner of Akwa Ibom State, Nigeria. It is bounded by Oruk Anam Local Government Area in the north, Mkpat Enin and Eastern Obolo Local Government Areas in the east and the Atlantic Ocean in the south (Figure 1). The Imo River forms the natural boundary in the west separating it from Rivers State. Ikot Abasi LGA is located geographical within $4^{0} 38$ $00^{\prime \prime} \mathrm{N}$ and $7^{0} 39^{\prime} 00^{\prime \prime} \mathrm{E}$. The people of Ikot Abasi are made up of the Ibibio ethnic group with diverse cultural heritage and tradition. They speak the Ibibio language. Ikot Abasi is made up of five clans namely: Ikpa Edemaya Clan, Ikpa Ibekwe Clan, Ikpa Nnung Assang Clan, Ukpum Ette Clan and Ukpum Okon Clan. The villages in Ikpa Ibekwe are: 1. Ata Udo-Usung; 2. Ikot Abasi; 3. Ikot Aba; 4. Ikot Akpan-Ata; 5. Ikot Essien; 6. Ikot Etetuk; 7. Ikot Obong; 8. Ikot Ukpo-Inua; 9. Ikpetim; and 10. Uta Ewa (Encyclopedia Britanica, 2017). The present day Ikot Abasi LGA was created in 1996 after the Mkpat Enin, Eastern Obolo, Oruk Anan, and Ukanagun LGAs were carved out of it (Encyclopedia Britanica, 2017). Ikot Abasi LGA falls under the tropical climate. Ikot Abasi LGA experiences two distinct seasons which are the dry and the rainy seasons with the latter lasting for much longer periods of the calendar year than the former. The average humidity level in Ikot Abasi LGA is 90 percent. The rainy season begins about March-April and lasts until mid-November. The study area receives relatively higher rainfall totals than other parts of southern Nigeria. The total annual rainfall varies from $4000 \mathrm{~mm}$ along the coast to $2000 \mathrm{~mm}$ inland (Online Nigeria, 2003). The dry season begins in mid-November and ends in March. During this brief period, the whole Continental Tropical air mass and its accompanying north-easterly winds and their associated dry and dusty harmattan haze. Temperature values are relatively high in Akwa lbom State throughout the year, with the mean annual temperatures varying between about $26^{\circ} \mathrm{C}$ to $36^{\circ} \mathrm{C}$ (Njungbwen et al, 2010). 
The geology of the study area is underlain by sedimentary formations of late Tertiary and Holocene ages (Njungbwen et al, 2010). Deposits of recent alluvium and beach ridge sands occur along the coast and the estuaries of the Imo and Qua lboe Rivers, and also along the flood-plains of creeks. A belt of shales associated with sandstones and limestones, north of Nkari and Obotme, extends down to ltu. The latter lithologies include the late Cretaceous Nsukka Formation at the base followed by the early Tertiary Imo Shale and the phosphatic Ameke Formation. Generally, the sands in Ikot Abasi are mature, coarse and moderately sorted. Quartz is the sole framework element, and monocrystalline quartz constitutes about two-thirds of the quartz varieties. The relief of the area lies entirely on the coastal plain of south-eastern Nigeria, where no part constitutes an area of appreciably high relief. Apart from the northern extreme corner of Obotme and Nkari and the north-eastern parts around ltu, Itam, Ibiono and Ini where the land is intensely dissected into a broken "valley and ridge" terrain, the landscape of Akwa lbom State comprises a generally low-lying plain and riverine areas with no portion exceeding $175 \mathrm{~m}$ above sea-level (Akwa Ibom State, 2014). Ikot Abasi LGA is the break in the mangrove swamp and rainforest of the eastern Niger River Delta (Encyclopedia Britanica, 2017). The mangrove swamps are succeeded landward by upland alluvial depositional terraces which extend into the valleys of the Imo, Kwa, lkpa and Enyong Rivers, where low natural levees descend into heavily forested back swamps. The existing climatic factors in Akwa lbom State would have favoured luxuriant tropical rainforests with teeming populations of fauna and extremely high terrestrial and aquatic biomass. The native vegetation is in the process of being replaced by secondary forests of predominantly wild oil palms, woody shrubs and various grass undergrowths (Njungbwen et al, 2010). The estimated population of Ikot Abasi LGA is 101,333 inhabitants with the most populous people being members of the Ibibio ethnic group. The Ibibio language is extensively spoken in the area while the religion of Christianity is widely practiced in the area. Popular landmarks in Ikot Abasi LGA include the Uta Ewa beach front and the Alscon Aluminium smelting plant (Federal Government of Nigeria, 2007). Farming is a key feature of the economic activities undertaken by the people of Ikot Abasi LGA with crops such as cassava, yam, maize, oil palm, coconut, and rubber grown in the area. Ikot Abasi LGA is also very rich in crude oil deposits with the area hosting a number of oil wells and fields. Other important economic engagements of the inhabitants of Ikot Abasi LGA include fishing, craftsmanship and woodwork (Online Nigeria, 2003). 


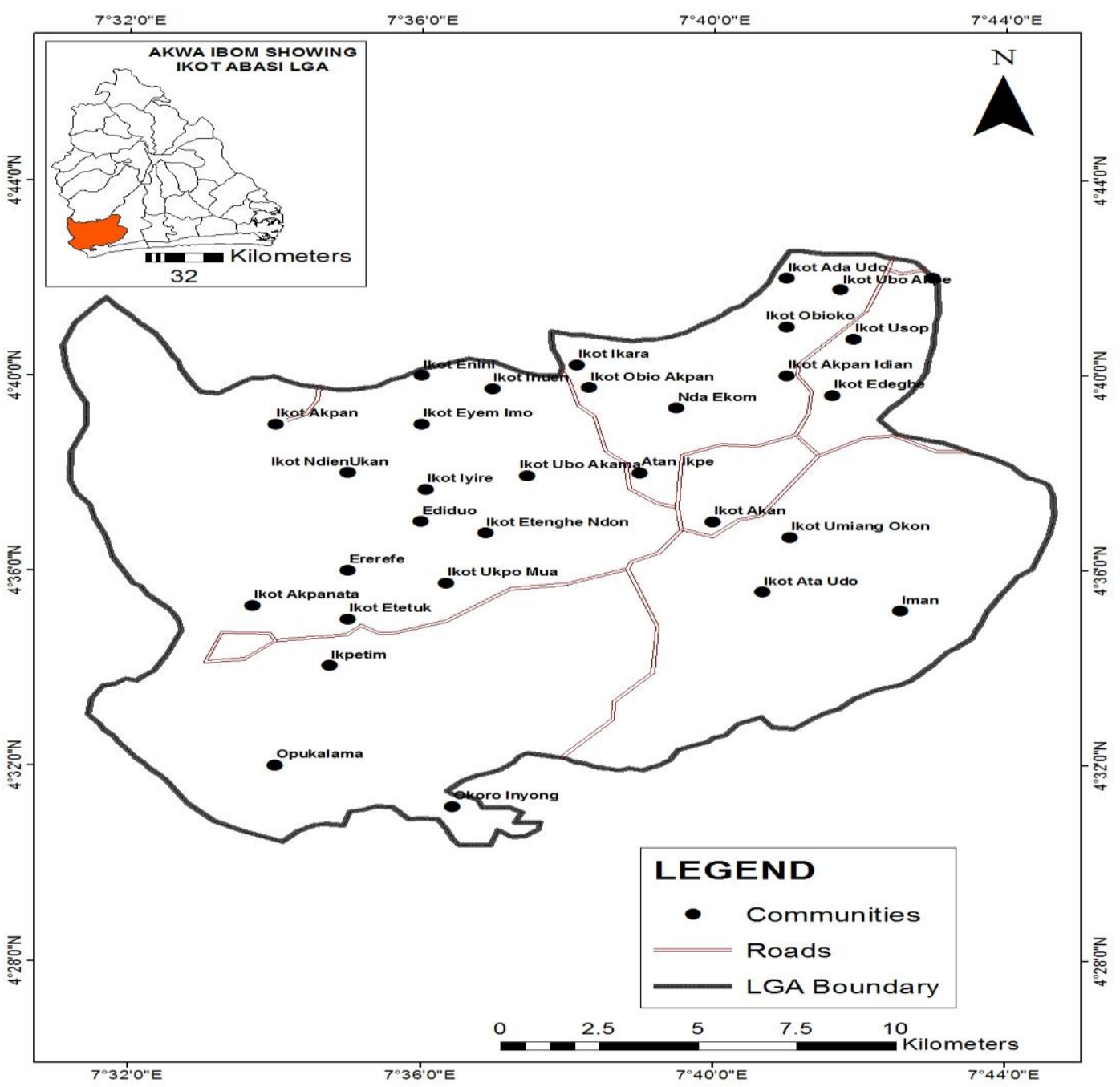

Figure 1. Ikot Abasi LGA of Akwa Ibom State

\section{RESEARCH DESIGN, RECONNAISSANCE SURVEY AND COLLECTION OF DATA}

The longitudinal research design was employed for the study because it is an observational research method in which data is gathered for the same subjects repeatedly over a period of time. Longitudinal research projects can extend over years or even decades. Reconnaissance survey was carried out to ascertain location for reference points in the study area. This gave an insight to familiarize with different types of land use in the study area. The visit to the place thus assisted to ground truth the land use types observed in the Landsat imagery. The ground-truthing was enhanced with the use of global positioning system (GPS) to determine the longitudes and latitudes of at least a location in each identified land use type (40 training sites were ground truthed with hand held GPS map 78sc). This study employed the use of Landsat imagery of 1986, 2000 and 2017 to determine the land use types for the different 
periods. The Landsat imageries were acquired from the United State Geological Survey (USGS, 2018) and the detail information of the imageries are shown in Table 1.

Table 1. Details of Landsat Imageries for the study

\begin{tabular}{|l|l|l|l|l|l|l|}
\hline Year & $\begin{array}{l}\text { Date } \\
\text { Acquired }\end{array}$ & Sensor & $\begin{array}{l}\text { Cloud } \\
\text { Cover }(\%)\end{array}$ & Path & Row & Resolution \\
\hline 1986 & $\begin{array}{l}\text { December } \\
19,1986\end{array}$ & Landsat 5 TM & 0 & 188 & 057 & $30 \mathrm{mx30m}$ \\
\hline 2000 & $\begin{array}{l}\text { December } \\
17,2000\end{array}$ & Landsat 7 ETM & 0 & 188 & 057 & $30 \mathrm{mx30m}$ \\
\hline 2017 & $\begin{array}{l}\text { January 4, } \\
2017\end{array}$ & $\begin{array}{l}\text { Landsat } \\
\text { OLI/TIRS }\end{array}$ & 0 & 188 & 057 & $30 \mathrm{mx30m}$ \\
\hline
\end{tabular}

Source: US Geological Survey, 2018

\section{Geoprocessing of Imageries and Landuse/Land cover Change Detection and Percentage Change}

Land use map of different periods of Akwa Ibom State was acquired from the Landsat imagery of 30m x 30m of 1986, 2000 and 2017 in order to delineate the LGA under study. Each image was geo-referenced in ArcGIS 10.5 to Universal Transverse Mercator, Zone 32N (WGS 84). Composite analysis was carried out for the bands of each image in each period in order to produce a false composite imagery in ArcGIS 10.5. From the ground-truthing of the land use types in the study area derived through reconnaissance survey, five landuse types were identified namely waterbodies, flood plain/riparian mangrove, thick vegetation, sparse/farmland and built up area (Table 2). The boundary of Ikot Abasi LGA was derived from the topographic map and this was used to clip the geo-referenced imageries so as the boundary showing the LGA can be maintained. In Erdas Imagine 9.1, training sites were generated from the imagery by capturing similar spectral reflectance in the imagery as same landuse based on the knowledge gained from the ground-truthing. The training sites were used to carry out supervised classification using the Maximum Likelihood Classification Algorithm. The land uses detected were subjected to accuracy assessment using Kappa's index. The spatial coverage of each land use type was determined in squared kilometers using the calculate geometry module of ArcGIS 10.5.

Table 2: Land use types and their Description

\begin{tabular}{|l|l|l|}
\hline S/N & Landuse Types & Description \\
\hline 1 & Water bodies & Rivers, streams, lakes, ponds etc. \\
\hline 2 & $\begin{array}{l}\text { Flood plain/Riparian } \\
\text { Mangrove }\end{array}$ & $\begin{array}{l}\text { Seasonal/temporal or permanent waterlogged areas with } \\
\text { undergrowth vegetation }\end{array}$ \\
\hline
\end{tabular}




\begin{tabular}{|l|l|l|}
\hline 3 & $\begin{array}{l}\text { Sparse } \\
\text { vegetation/Farmland }\end{array}$ & $\begin{array}{l}\text { Grass fields, ferns, footpaths etc. and agricultural area, } \\
\text { crop fields, barren lands etc. }\end{array}$ \\
\hline 4 & Thick vegetation & $\begin{array}{l}\text { Thick forest, derived forest, mixed forest lands, palms, } \\
\text { conifer, Scrubs, herbs and others }\end{array}$ \\
\hline 5 & Built up area & $\begin{array}{l}\text { Residential, commercials and services, transportation, } \\
\text { roads etc. }\end{array}$ \\
\hline
\end{tabular}

The area of land use in each year was calculated and simple arithmetic was done by subtracting the area of land use in initial year from the final year. Thus, the area of each land use types in previous period was subtracted from the area of the same land use in the next period. The difference gave the land use change in terms of spatial coverage and direction of changes. The percentage change of each land use was then computed to determine the percentage increase or decrease of each land use using the formula below:

LU Final - LU Initial x 100 Equ. 1.

Thus, the land use of the previous period was overlaid on the next to detect the land use that was changed in the present period and the spatial coverage in squared kilometres $\left(\mathrm{km}^{2}\right)$.

\section{Analysis of Data}

Descriptive statistics was used to explain the values of forest resources (thick vegetation) change and the percentage change in the thick vegetation per year under consideration. Analysis of variance (ANOVA) was used to determine the significant variation in the landuse extent between 1986 and 2017. This statistical tool helps to determine the variation in a data set with reference to variation within, between and among samples in a distribution. All the statistical analyses for the study were computed using Statistical Package for Social Scientists (SPSS) Version 24.0 and Microsoft Excel 2010 Version.

\section{RESULTS AND DISCUSSIONS}

\section{Landuse Changes between 1986 and 2017}

The land use analyses for 1986, 2000 and 2017 imageries obtained for the study were displayed on Figures 2, 3 and 4 and Table 3. The analysis for the year 1986 land use/ land cover displayed revealed that the area occupied by waterbodies was $37.52 \mathrm{~km}^{2}$; the size of floodplain was 130.68 $\mathrm{km}^{2}$; thick vegetation recorded area coverage of $142.90 \mathrm{~km}^{2}$; sparse vegetation or farmland was $15.24 \mathrm{~km}^{2}$; and built up area recorded $33.20 \mathrm{~km}^{2}$ respectively. In the year 2000 , the land use analysis revealed that waterbodies size increased to $39.71 \mathrm{~km}^{2}$; floodplain size reduced to 102.45 $\mathrm{km}^{2}$; thick vegetation's area coverage slightly increased in size to $143.32 \mathrm{~km}^{2}$; sparse vegetation or farmland area coverage reduced to $10.36 \mathrm{~km}^{2}$; while the built up area land use increased considerably to $63.70 \mathrm{~km}^{2}$. 
Consequently, the year 2017 observed a dramatic change in the size/area coverage of thick vegetation which reduced to $20.62 \mathrm{~km}^{2}$ from $143.32 \mathrm{~km}^{2}$; however, waterbodies further increased to $66.74 \mathrm{~km}^{2}$; floodplain are coverage also increased to $106.17 \mathrm{~km}^{2}$ from the initial $102.45 \mathrm{~km}^{2}$ which reduced from $130.68 \mathrm{~km}^{2}$ in 1986 . In the same vein, area converted to sparse vegetation or farmland also further reduced to $6.05 \mathrm{~km}^{2}$; while built up area increased significantly from $63.70 \mathrm{~km}^{2}$ to $159.96 \mathrm{~km}^{2}$. The study therefore concluded that no much developmental changes were observed in the years between 1986 and 2000 because of the land use/land cover changes experienced in the study area. However, the years between 2000 and 2017 recorded significant changes in the land use/ land cover as the size and area coverage of thick vegetation reduced from $143.32 \mathrm{~km}^{2}$ to $20.62 \mathrm{~km}^{2}$ (within a space of 17 years). Thus, more developmental projects occurred in the study area which significantly impacted on the thick vegetation land use/ land cover which was mostly effected by the built up area land use. The study also revealed based on the analysis that the increase in the floodplain area coverage may be attributed to the creation of more open land which were now subjected to flood as a result of increase in the size of waterbodies from $37.52 \mathrm{~km}^{2}$ in 1986 to $66.74 \mathrm{~km}^{2}$ in 2017.

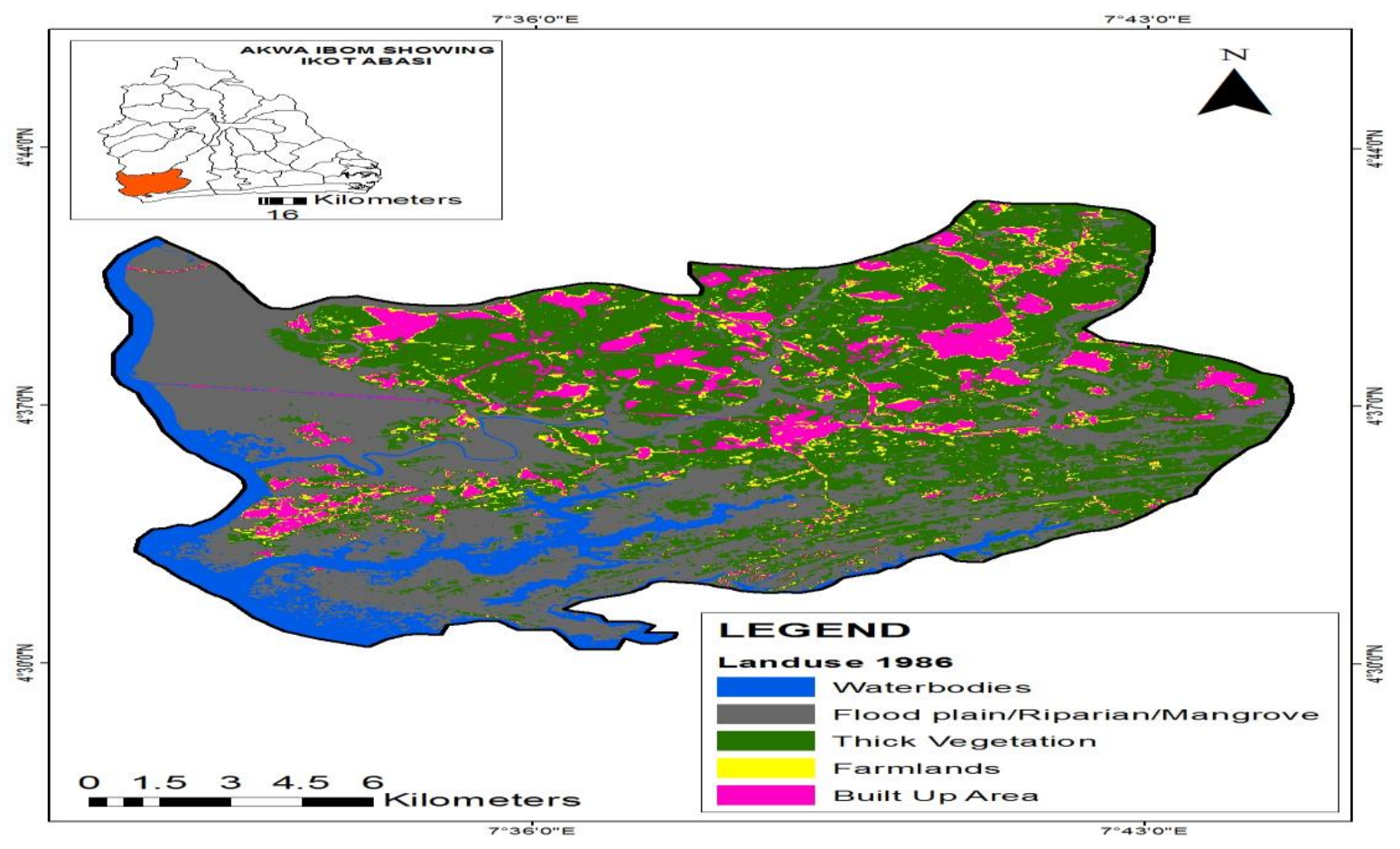

Figure 2: Land use/Land Cover in year 1986 
International Journal of Agriculture, Environment and Bioresearch

Vol. 4, No. 06; 2019

ISSN: $2456-8643$

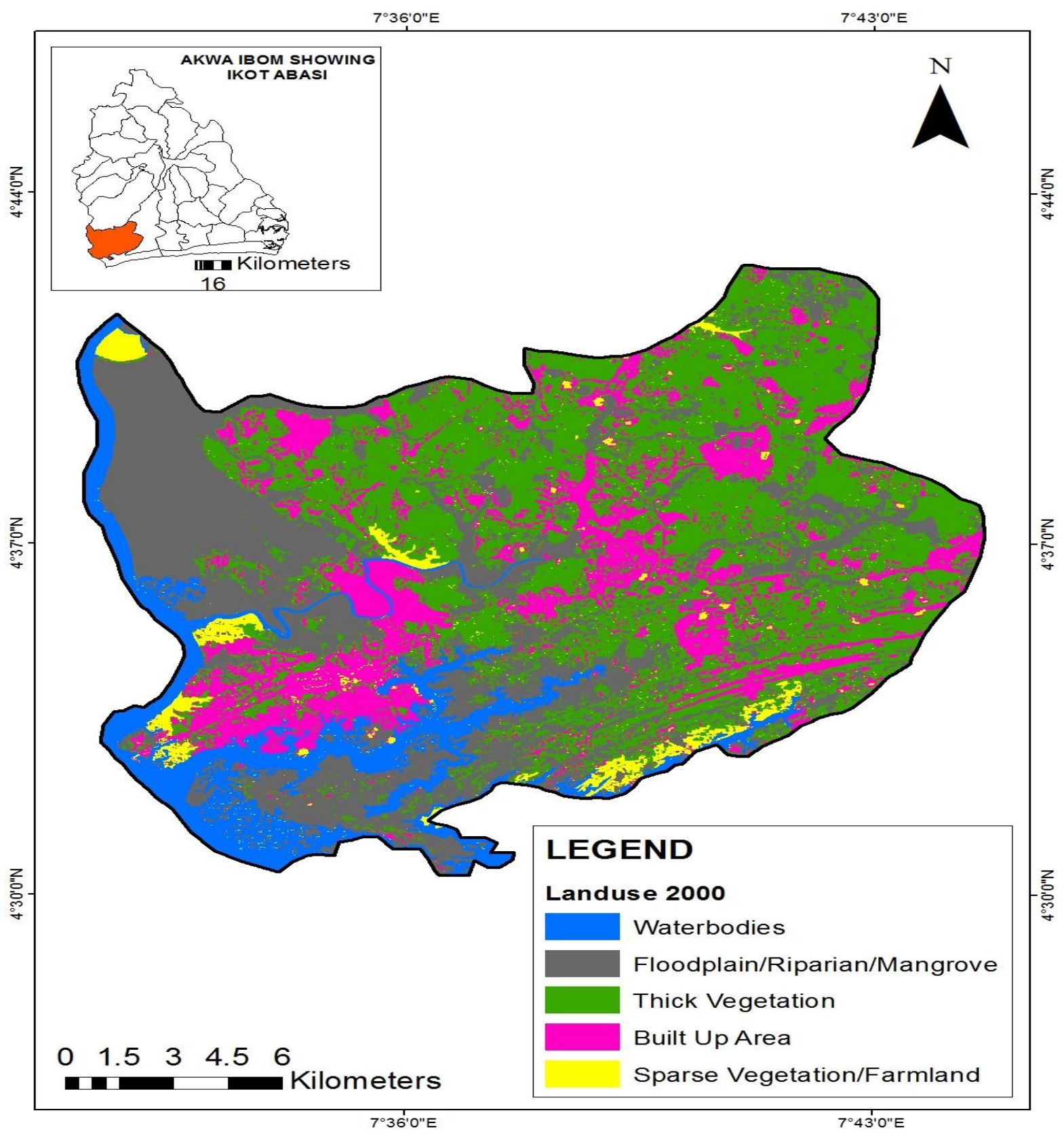

Figure 3: Land use/ Land cover in year 2000 
International Journal of Agriculture, Environment and Bioresearch

Vol. 4, No. 06; 2019

ISSN: $2456-8643$

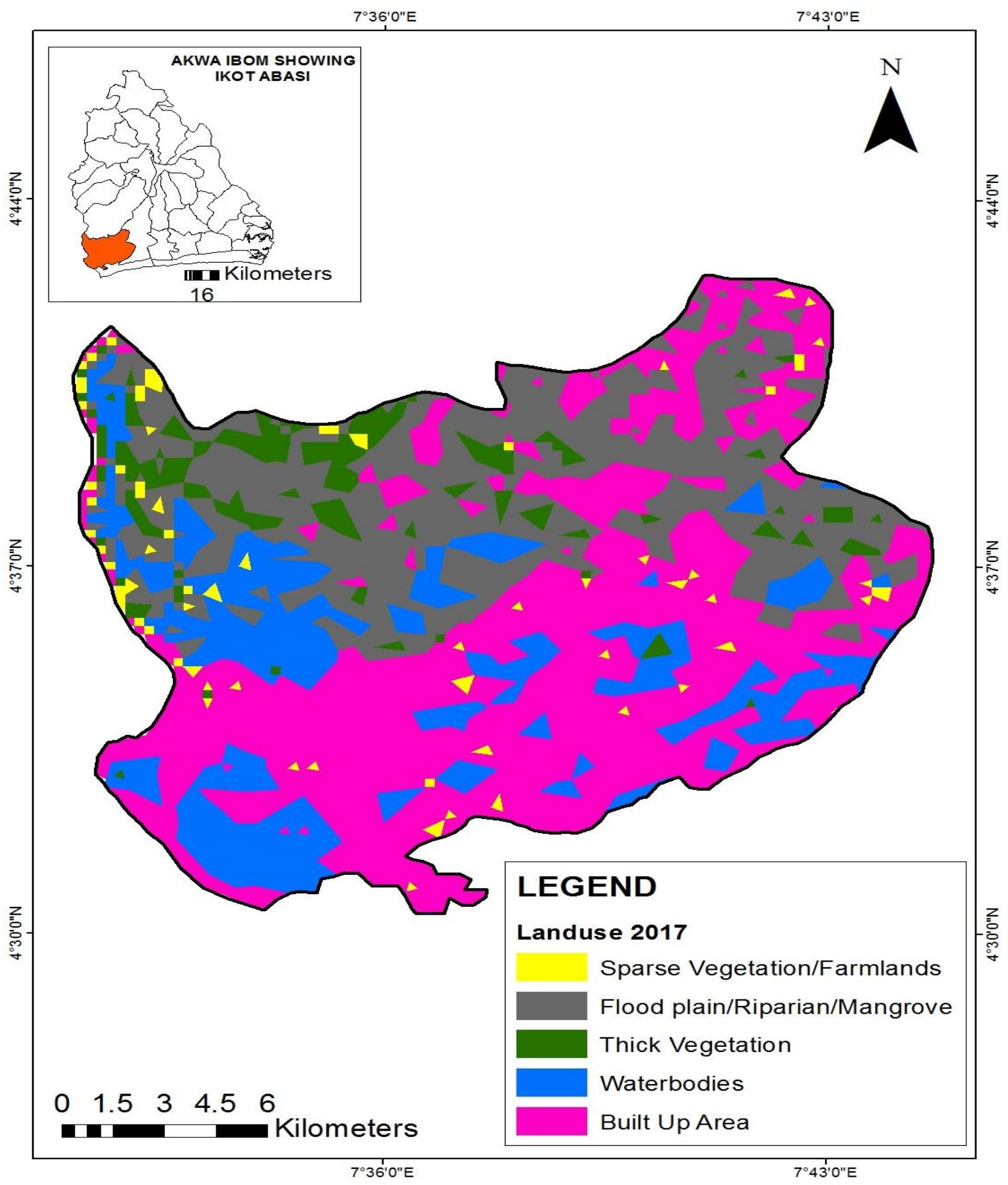

Figure 4: Land use/ Land cover in year 2017 
International Journal of Agriculture, Environment and Bioresearch

Vol. 4, No. 06; 2019

ISSN: $2456-8643$

Table 3: Periodic Changes of Land use/Land cover between 1986 and 2017

\begin{tabular}{|l|l|l|l|l|l|l|}
\hline $\begin{array}{l}\text { Land use/land } \\
\text { cover }\end{array}$ & $\begin{array}{l}\mathbf{1 9 8 6} \\
\left(\mathbf{k m}^{2}\right)\end{array}$ & $\begin{array}{l}\text { Percentage } \\
(\mathbf{\%})\end{array}$ & $\begin{array}{l}\mathbf{2 0 0 0} \\
\left(\mathbf{k m}^{2}\right)\end{array}$ & $\begin{array}{l}\text { Percentage } \\
(\boldsymbol{\%})\end{array}$ & $\begin{array}{l}\mathbf{2 0 1 7} \\
\left(\mathbf{k m}^{2}\right)\end{array}$ & $\begin{array}{l}\text { Percentage } \\
(\mathbf{\%})\end{array}$ \\
\hline Waterbodies & 37.52 & 10.4 & 39.71 & 11.0 & 66.74 & 18.6 \\
\hline Floodplain/Riparian & 130.68 & 36.3 & 102.45 & 28.5 & 106.17 & 29.5 \\
\hline Thick Vegetation & 142.90 & 39.7 & 143.32 & 39.9 & 20.62 & 5.7 \\
\hline $\begin{array}{l}\text { Sparse vegetation or } \\
\text { Farmland }\end{array}$ & 15.24 & 4.2 & 10.36 & 2.9 & 60.5 & 16.8 \\
\hline Built up Area & 33.20 & 9.2 & 63.70 & 17.7 & 159.96 & 44.5 \\
\hline Total & $\mathbf{3 5 9 . 5 4}$ & $\mathbf{1 0 0 . 0}$ & $\mathbf{3 5 9 . 5 4}$ & $\mathbf{1 0 0 . 0}$ & $\mathbf{3 5 9 . 5 4}$ & $\mathbf{1 0 0 . 0}$ \\
\hline
\end{tabular}

\section{Periodic Changes in Size of Forest Cover between 1986 and 2017}

The periodic changes in size of forest cover were displayed on Figures 5, 6 and 7. The maps utilized for this purpose clearly showed how the size or spatial extent of forest cover in Ikot Abasi, Akwa Ibom State depreciated over time between 1986 and 2017.

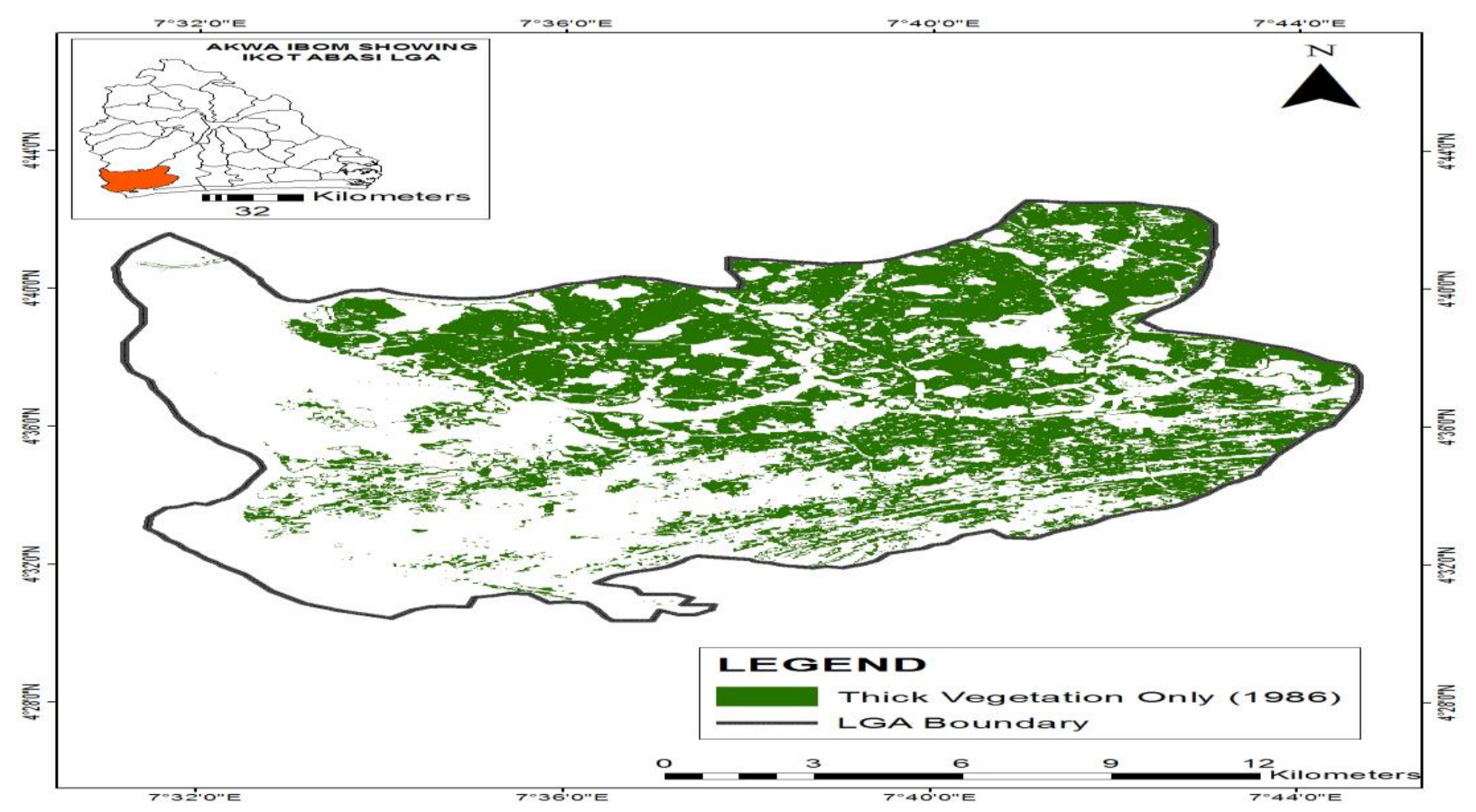

Figure 5: Forest Cover only in Ikot Abasi LGA in 1986 
International Journal of Agriculture, Environment and Bioresearch

Vol. 4, No. 06; 2019

ISSN: $2456-8643$

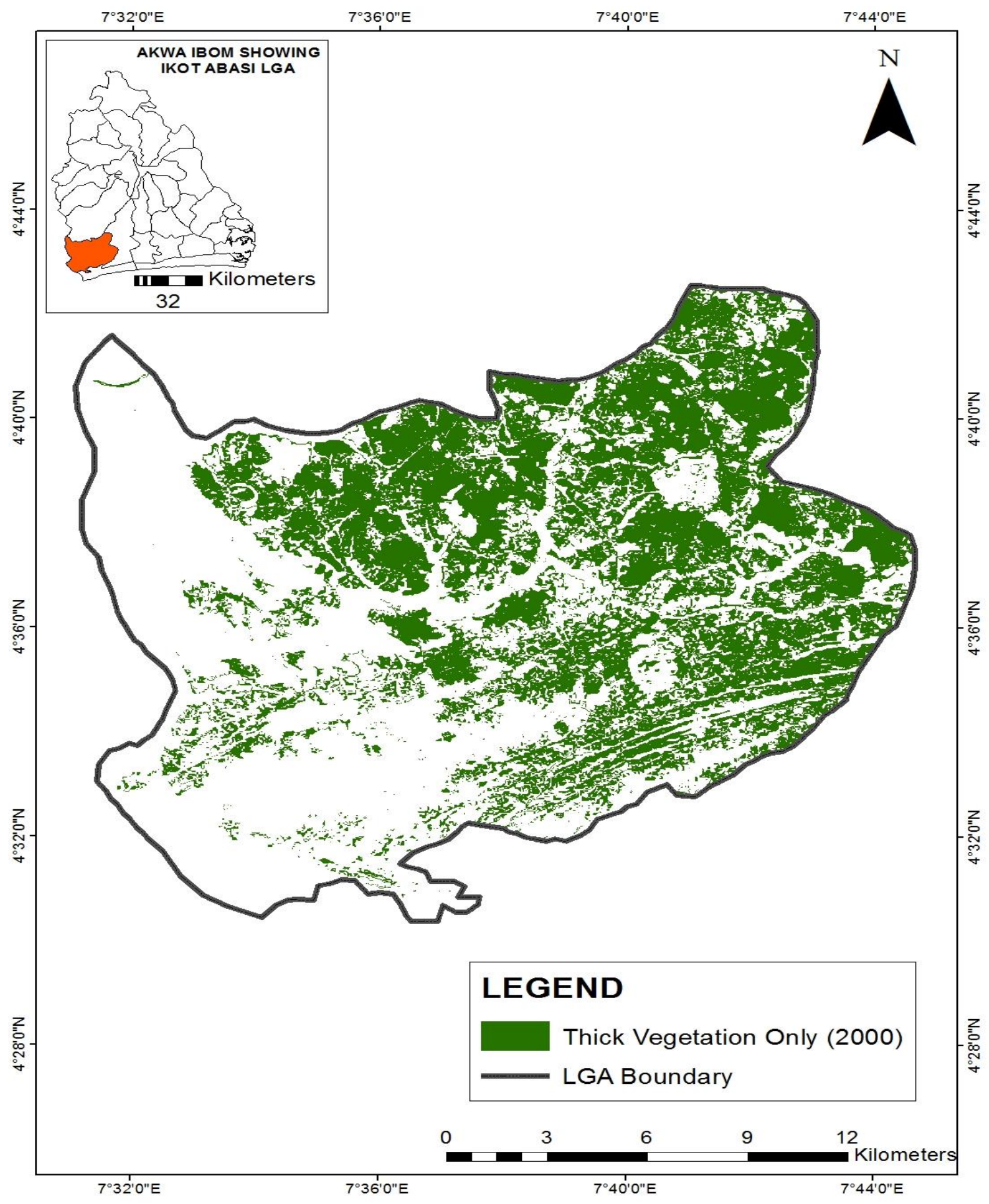

Figure 6: Forest Cover only in Ikot Abasi LGA in 2000 
International Journal of Agriculture, Environment and Bioresearch

Vol. 4, No. 06; 2019

ISSN: $2456-8643$

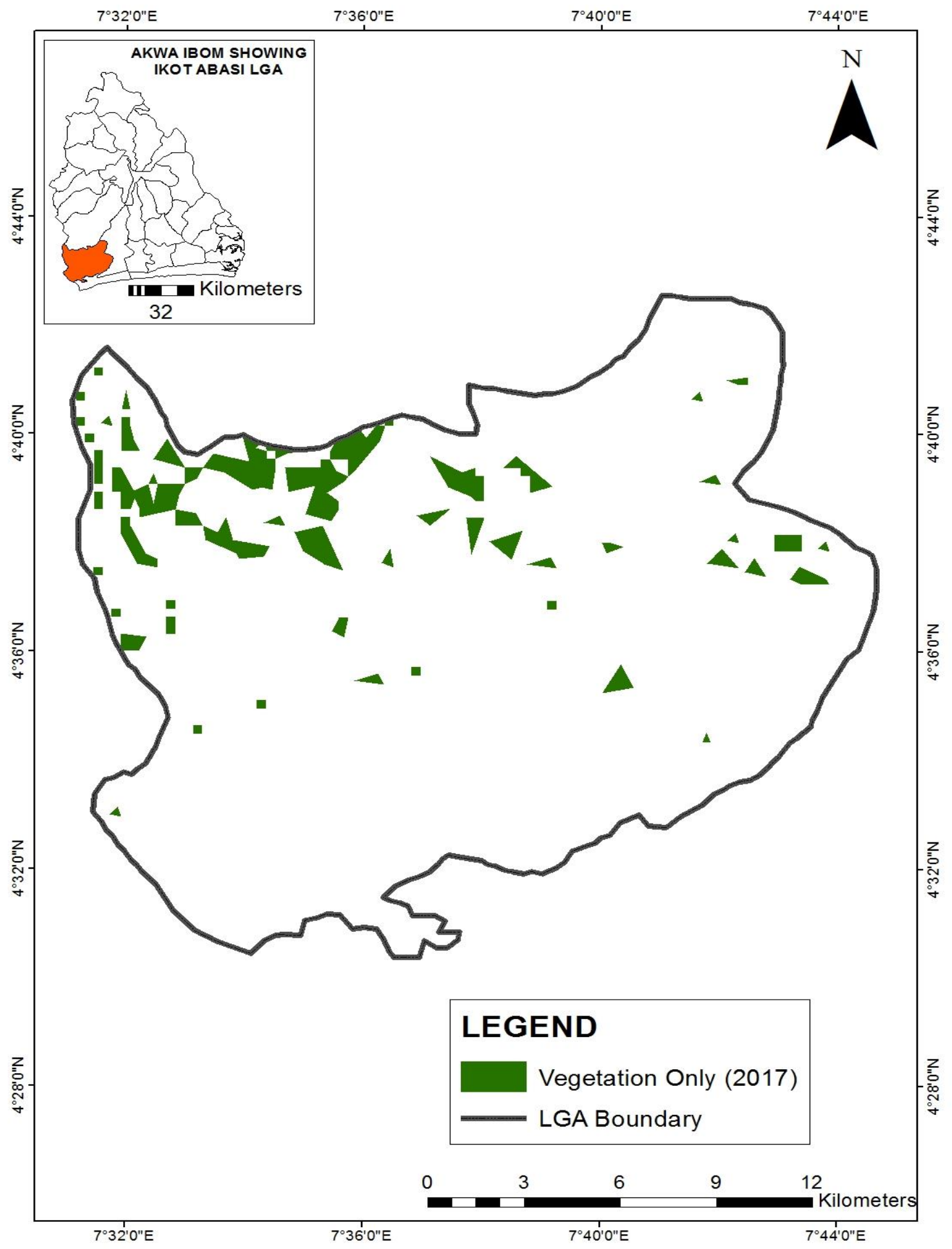

Figure 7: Forest Cover only in Ikot Abasi LGA in 2017 


\section{Percentage Changes in Land use Types and Forest Cover (1986 and 2017)}

The percentage change in land use types and forest cover was displayed on Table 4. The analysis showed that waterbodies recorded a change of $2.19 \mathrm{~km}^{2}$ between 1986 and 2000 with a percentage change of 5.84; and further changed to $27.03 \mathrm{~km}^{2}$ and percentage change of 68.07 between 2000 and 2017 (total change $=29.22 \mathrm{~km}^{2}$ and \% change 73.91). The floodplain/ riparian mangrove recorded change of $28.23 \mathrm{~km}^{2}$ and a percentage change of 21.60 between 1986 and 2000. Consequently between 2000 and 2017, it recorded a change of $3.72 \mathrm{~km}^{2}$ and 3.63 percentage change (total change $=24.51 \mathrm{~km}^{2}$ and $\%$ change 17.97). Thick vegetation (forest cover) increased slightly recording a change of $0.42 \mathrm{~km}^{2}$ and a percentage change of 0.29 . However, between 2000 and 2017, the size reduced significantly recording a change of -122.7 $\mathrm{km}^{2}$ and percentage change of 85.61 (total change was $-122.28 \mathrm{~km}^{2}$ and \% change of 85.32). Sparse vegetation/ Farmland land use type recorded change of $4.88 \mathrm{~km}^{2}$ and a percentage change of 32.02 between 1986 and 2000; but increased with a change of $50.14 \mathrm{~km}^{2}$ and percentage change of 483.9 between 2000 and 2017 (total change of 45.26 and \% change of 451.88). The built up are recorded significant changes of $+30.5 \mathrm{~km}^{2}$ (\% change of 91.87) between 1986 and 2000 and a change of $+96.26 \mathrm{~km}^{2}$ and a \% change of 151.11 (total change was $126.76 \mathrm{~km}^{2}$ and \% change of 242.98).

Table 4. Percentage Change in Land use Types and Forest cover between 1986 and 2017

\begin{tabular}{|c|c|c|c|c|c|c|c|c|c|c|}
\hline Land use & $\begin{array}{l}1986 \\
\left(\mathrm{~km}^{2}\right)\end{array}$ & $\begin{array}{l}2000 \\
\left(\mathrm{~km}^{2}\right)\end{array}$ & $\begin{array}{l}\text { Chan } \\
\text { ge } \\
\left(\mathrm{km}^{2}\right. \\
)\end{array}$ & $\begin{array}{l}\% \\
\text { chang } \\
\mathrm{e}\end{array}$ & $\begin{array}{l}2000 \\
\left(\mathrm{~km}^{2}\right)\end{array}$ & $\begin{array}{l}2017 \\
\left(\mathrm{~km}^{2}\right)\end{array}$ & $\begin{array}{l}\text { Chan } \\
\text { ge } \\
\left(\mathrm{km}^{2}\right)\end{array}$ & $\begin{array}{l}\% \\
\text { chan } \\
\text { ge }\end{array}$ & $\begin{array}{l}\text { Total } \\
\text { chang } \\
\mathrm{e}\end{array}$ & $\begin{array}{l}\text { Total } \\
\% \\
\text { chan } \\
\text { ge } \\
(198 \\
6- \\
2017 \\
)\end{array}$ \\
\hline Waterbodies & 37.52 & 39.71 & -2.19 & $\begin{array}{l}-5.84 \\
\end{array}$ & 39.71 & 66.74 & $\begin{array}{l}- \\
27.03\end{array}$ & $\begin{array}{l}- \\
68.0 \\
7\end{array}$ & -29.22 & 73.91 \\
\hline $\begin{array}{l}\text { Floodplain/R } \\
\text { iparian }\end{array}$ & $\begin{array}{l}130.6 \\
8\end{array}$ & $\begin{array}{l}102.4 \\
5\end{array}$ & $\begin{array}{l}28.2 \\
3\end{array}$ & 21.60 & $\begin{array}{l}102.4 \\
5\end{array}$ & $\begin{array}{l}106.1 \\
7\end{array}$ & $\begin{array}{l}-3.72 \\
\end{array}$ & -3.63 & 24.51 & 17.97 \\
\hline $\begin{array}{l}\text { Thick } \\
\text { Vegetation }\end{array}$ & $\begin{array}{l}142.9 \\
0\end{array}$ & $\begin{array}{l}143.3 \\
2\end{array}$ & -0.42 & -0.29 & $\begin{array}{l}143.3 \\
2\end{array}$ & 20.62 & 122.7 & $\begin{array}{l}85.6 \\
1\end{array}$ & $\begin{array}{l}122.2 \\
8\end{array}$ & $\overline{85.32}$ \\
\hline $\begin{array}{l}\text { Sparse } \\
\text { vegetation or } \\
\text { Farmland }\end{array}$ & 15.24 & 10.36 & 4.88 & 32.02 & 10.36 & 60.5 & $\begin{array}{l}- \\
50.14\end{array}$ & $\begin{array}{l}- \\
483 . \\
9\end{array}$ & -45.26 & $\begin{array}{l}451.8 \\
8\end{array}$ \\
\hline Built up & 33.20 & 63.70 & -30.5 & -91.87 & 63.70 & 159.9 & - & $\begin{array}{l}- \\
151 .\end{array}$ & $-\overline{-}$ & 242.9 \\
\hline
\end{tabular}




\begin{tabular}{|l|l|l|l|l|l|l|l|l|l|l|}
\hline Area & & & & & & 6 & 96.26 & 11 & 6 & 8 \\
\hline
\end{tabular}

\section{Variation in Land use Types in 1986, 2000 and 2017}

The computed variation in land use in year 1986 showed that the area extent for individual land use/ land cover varied significantly and this was displayed on Table 5. This was because the level of significance of 0.006 was lower than the p-value of 0.05 , which means that the variation among land use/land cover was considerable. The computed variation in land use in the year 2000 showed that the area extent for individual land use/ land cover varied significantly and this was displayed on Table 6 . This was because the level of significance of 0.004 was lower than the p-value of 0.05 ; which means that the variation among land use/land cover was considerable, that is, they differ in size or area extent. The computed variation in land use in the year 2017 showed that the area extent for individual land use/ land cover varied significantly and this was displayed on Table 7. This was because the level of significance of 0.001 was lower than the p-value of 0.05 ; which means that the variation among land use/land cover was considerable, that is, they differ in size or area extent. Table 8 showed that the variation was significant as the level of significance of 0.032 was less than 0.05 probability value. Thus, there is a significant variation in land use types between 1986 and 2017.

Table 5. Variation among land use/land cover in 1986

\begin{tabular}{|llllll|}
\hline Land use & $\begin{array}{l}\text { Sum } \\
\text { Squares }\end{array}$ & $\begin{array}{c}\text { of } \\
\text { of freedom) }\end{array}$ & $\begin{array}{l}\text { Mean Square } \\
\text { of } \text { F ratio }\end{array}$ & $\begin{array}{l}\text { Level of } \\
\text { Significance } \\
\text { (p value) }\end{array}$ \\
\hline $\begin{array}{l}\text { Between } \\
\text { groups }\end{array}$ & 6.922 & 4 & 1.839 & 4.231 & 0.006 \\
$\begin{array}{l}\text { Within } \\
\text { Groups }\end{array}$ & 4622.813 & 9135 & 0.706 & & \\
Total & 4629.735 & 9139 & & & \\
\hline
\end{tabular}

Table 6. Variation among land use/land cover in 2000

\begin{tabular}{|llllll|}
\hline Land use & $\begin{array}{l}\text { Sum } \\
\text { Squares }\end{array}$ & of $\begin{array}{l}\text { Df(Degree of } \\
\text { freedom) }\end{array}$ & Mean Square & F ratio & $\begin{array}{l}\text { Level of } \\
\text { Significance } \\
\text { (p value) }\end{array}$ \\
\hline $\begin{array}{l}\text { Between } \\
\text { groups }\end{array}$ & 6.695 & 4 & 1.342 & 3.733 & 0.004 \\
\hline
\end{tabular}




\begin{tabular}{|lrrr|}
\hline $\begin{array}{l}\text { Within } \\
\text { Groups }\end{array}$ & 4531.628 & 9031 & 0.655 \\
Total & 4538.323 & 9035 & \\
\hline
\end{tabular}

Table 7. Variation among land use/land cover in 2017

\begin{tabular}{|c|c|c|c|c|c|c|}
\hline Land use & $\begin{array}{l}\text { Sum } \\
\text { Squares }\end{array}$ & of & $\begin{array}{l}\mathrm{Df}(\text { Degree of } \\
\text { freedom) }\end{array}$ & Mean Square & F ratio & $\begin{array}{l}\text { Level of } \\
\text { Significance } \\
\text { (p value) }\end{array}$ \\
\hline $\begin{array}{l}\text { Between } \\
\text { groups }\end{array}$ & 6.779 & & 4 & 2.784 & 7.011 & 0.001 \\
\hline $\begin{array}{l}\text { Within } \\
\text { Groups }\end{array}$ & 4662.871 & & 9441 & 0.901 & & \\
\hline Total & 4669.650 & & 9445 & & & \\
\hline
\end{tabular}

Table 8. Analysis of Variance (ANOVA) Land use Types varies between 1986 and 2017

\begin{tabular}{|llllll|}
\hline Land uses & $\begin{array}{l}\text { Sum of } \\
\text { Squares }\end{array}$ & $\begin{array}{l}\text { Df (Degree } \\
\text { of freedom) }\end{array}$ & Mean Square & F ratio & $\begin{array}{l}\text { Level of Significance } \\
\text { Level (at p=0.05) }\end{array}$ \\
\hline $\begin{array}{l}\text { Between } \\
\text { groups }\end{array}$ & 4.555 & 2 & 2.339 & 3.223 & 0.032 \\
$\begin{array}{l}\text { Within } \\
\text { Groups }\end{array}$ & 26578.542 & 36781 & 0.735 & & \\
Total & 26583.097 & 36783 & & & \\
\hline
\end{tabular}

\section{DISCUSSION OF FINDINGS}

The study discovered that vegetation size/area extent reduced to $20.62 \mathrm{~km}^{2}$ (5.7\%) in 2017 from $142.90 \mathrm{~km}^{2}$ in 1986 (39.7\%); which recorded about 34\% total land loss to other land use/ land cover types. This shows that forested areas decreased in terms of spatial extent between 1986 and 2017. This is as a result of the fact that forest cover is being converted to other land use types which usually are farming and flood plain/riparian areas and mostly built up areas. The major drivers of these processes are population increase and the new road fashioned out to link Rivers State and Akwa Ibom State through the Ogoni land road and Ikot Abasi road. This necessitated the need for land to be converted for socio-economic purposes in the LGA. This finding 
corroborates with Obiefuna et al. (2013) which revealed that the obvious consequence of the population expansion on natural resources are evident when the need arises for socio-economic development. Similarly, rapid urbanization is known to generate negative impacts on the environment as it leads to changes in landscape patterns, ecosystem functions and the capacity to perform functions in support of human populations (UN-Habitat, 2010). It would be right to say that reduction in forest cover area extent will mean reduction in forest resources composition and diversity in the study area. Consequently, the land use that actually gained the most (increased overtime) among identified land use from the analysis was the built up area land use which increased significantly from $33.20 \mathrm{~km}^{2}(9.2 \%)$ in 1986 to $159.96 \mathrm{~km}^{2}(44.5 \%)$ in the year 2017 with a total percentage change of 242.98 in relation to other land use types. This finding is in line with the findings of Bankole and Bakare (2011) whereby it was stated that expansion of human settlements as regards the built up area and its accompanying activities, especially the rapid urbanization occurring in the developing countries, play an important role in global land use and cover change, causing changes in the ecological processes at both local and global scales. The continuous increase in built up areas is due to increase in the inflow of population that places heavy demand on the environment by promoting greater increase in the number of settlements especially along road network and expansion activities within the suburbs. The decrease experienced in thick vegetation and water bodies land uses between 1986 and 2017 is directly linked to human activities through forest removal and exploitation. The works of Olajuyigbe et al., (2015) confirmed that vegetation and water bodies have been greatly tampered with, as a result of human activities through exploitation and development of built up areas. It was also noted in the findings that sparse vegetated areas or farmland reduced in spatial extent in the year 2000 by $1.3 \%$, which may be due to people abandoning farming for other activities or jobs like white collar jobs. Reduction in sparse vegetation/farmland could also mean increase in the derived forest because farmlands were abandoned. However, there was increase in area extent between 2000 and 2017 indicating that more farmlands were acquired. Lambin et al, (2013) reported that humans have increased agricultural output mainly by bringing more land into production.

The encroachment activities are evident when one considers the rate or increase in built up area land use. This finding is in support of Dewan and Yamagushi (2009) that monitored land use and land cover changes in Dhaka metropolitan, Bangladesh between 1960 and 2005, and discovered that urban built-up areas increased significantly from $11 \%$ to $334 \%$ which is mainly attributed to the fast increase of population in the study area. Meyer (2013) also agreed that human activity has been the major threat to vegetation. The results of the analysis revealed that there was a significant variation in the spatial extent (size) of the forest cover between 1986 and 2017. Therefore, land use change effect has been felt on forest resources in the study area and it was noted that the built up area (anthropogenic activities) land use has contributed 35.3\% to this change.

\section{CONCLUSION AND RECOMMENDATIONS}

It can be concluded that the study has revealed the effect of land use change on forest resources in Ikot Abasi LGA. The study revealed that the size of forest cover has reduced greatly between 1986 and 2017. Furthermore, the study exposed that increase in human activities for socio- 
economic reasons have exerted pressure on land, thereby causing loss in forest resources overtime in the study area. The study recommended that:

1. Anthropogenic activities currently effecting reduction in the size of forest cover should be controlled.

2. Forest management and conservation strategies should be put in place so that forested areas that need to be protected can be protected and preserved.

3. Sensitization efforts should be encouraged to stimulate the change in the orientation of the rural dwellers and the inhabitants of the area towards the roles and importance of forest and vegetal cover to the environment.

4. Regular research is needed to ensure that adequate information is gathered as regards forest cover status to promote effective management of forest resources.

5. Government should as a matter of urgency put in place laws to regulate the activities constantly depleting the forest covers in the study area.

\section{REFERENCES}

Abubakar, A.A. (2015). Effects of urbanization on landuse/landcover changes in Birnin Kebbi, Kebbi State, Nigeria. Being a thesis submitted to the School Of Post Graduate Studies, Ahmadu Bello University, Zaria, in partial fulfillment of the requirements for the award of Master Of Science Degree In Remote Sensing And Geographic Information System, Department of Geography, A.B.U Zaria.

Ajibola, M.O., Adewale, B.A., and Ijasan, K.C. (2012). aaEffects of Urbanisation on Lagos Wetlands Mgt. Journal of Bus. and Soc. Sd. Vol. 3. No. 17

Bankole M. O. and Bakare H. O. (2011). Dynamics of urban land use changes with remote sensing: Case of Ibadan, Nigeria. Journal of Geography and Regional Planning Vol. 4(11), pp. 632-643.

Bedru, S.M. (2016). Remote Sensing \& GIS for Land Cover/ Land Use Change Detection and Analysis in the Semi-Natural Ecosystems and Agriculture Landscapes of the Central Ethiopian Rift Valley. Doctoral Dissertation. Dresden, Germany

Brown S, Zarin D. (2013). What does zero deforestation mean? Science. 342:805-807.

Chen, D., J. Chen, Z. Luo, and Z. Lv, (2010). Emergy evaluation of the natural value of water resources in Chinese rivers. Environmental Management, vol. 44, no. 2, pp. 288-297

Chen, D., M. Webber, J. Chen, and Z. Luo, (2011). Emergy evaluation perspectives of an irrigation improvement project proposal in China. Ecological Economics, vol. 70, no. 11, pp. 2154-2162

Chen, Y., Wang, B., Pollino, C., and Merrin, L., (2012). Spatial modelling of potential soil water retention under floodplain inundation using remote sensing and GIS. International Environmental Modelling and Software Society (iEMSs) 2012 International Congress on Environmental Modelling and Software Managing Resources of a Limited Planet, Sixth Biennial Meeting, Leipzig, Germany in R. Seppelt, A.A. Voinov, S. Lange, D. Bankamp (Eds.). http://www.iemss.org/society/index.php/iemss-20 12- proceedings 
Dewan, A.M., and Yamagushi, Y. (2009). Using Remote Sensing and GIS to detect and monitor landuse and land cover change in Dhaka metropolitan of Bangladesh during 19602005. Environ. Monit. Assess; 150:237-249

De Sherbinin, A. (2002). Land-Use and Land-Cover Change, A CIESIN Thematic Guide. Center for International Earth Science Information Network (CIESIN) of Columbia University, Palisades, NY, USA. http://www.sedac.ciesin-columbiaedu/tg/guide_maiin.jsp Accessed on October, 28, 2018.

Dutt, C.B.S, Udayalakshmt, V, Sadhasivaiah, A.S. (2016). Role of Remote sensing in Forest Management. Available at: https://www.geospatialworld.net/article/role-of-remotesensing-in-forest-management/

Encyclopedia Britannica (2017). Ikot Abasi, Nigeria. https://en.wikipedia.org/wiki/Ikot-Abasi Retrieved 2018-09-22.

Food and Agricultural Organisation (FAO) (2015). Global forest resources assessment. How are the world's forests changing? Rome: FAO.

Hansen MC, Potapov PV, Moore R, Hancher M, Turubanova S, Tyukavina A, Thau D, Stehman S, Goetz S, Loveland T. (2013). High-resolution global maps of 21st-century forest cover change. Science. 342:850-853.

Kolbaek, R. (2014). Research Designs. Lecture for the WIP 2014 at Malta IRIS-network. http://irisnetwork.shareponit.com/WIP2014Malta/Dr.K/.../Last visited 2018-09-13

Lambin E.F., Geist H.J., and Lepers, H. (2013). Dynamics of land-use and land- cover Change in tropical regions Annu. Rev. Environ. Resources, Vol.28: pp 20-41.

Li, R.Q., M. Dong, J.-Y. Cui, L.-L. Zhang, Q.-G. Cui, and W.-M. He, (2012). Quantification of the impact of land-use changes on ecosystem services: a case study in Pingbian County, China. Environmental Monitoring and Assessment, vol. 128, no. 1-3, pp. $503-510$

Melese, S.M. (2016). Effect of Land Use Land Cover Changes on the Forest Resources of Ethiopia. International Journal of Natural Resource Ecology and Management Volume 1, Issue 2, Pages: 51-57

Mendoza-González, M., M. Martínez, D. Lithgow, O. Pérez-Maqueo, and P. Simonin, (2012). Land use change and its effects on the value of ecosystem services along the coast of the Gulf of Mexico. Ecological Economics, vol. 82, pp. 23-32

Meyer, R. (2013). Major Threats to Wetlands. www.texaswetlands.org/majorthreats. towetlands. Retrieved online 2015-02-08

Nachmias, C.F., and Nachmias, D. (2006).Research Methods in Social Sciences.http://books.google.com.ng/books?isbn=1572599294

Obiefuna, J.N., Nwilo, P. C., Atagbaza, A. 0. andOkolie, C. J. (2013). Spatial Changes in the Wetlands of Lagos Lekki Lagoons of Lagos, Nigeria. Journal of Sustainable Development; Vol. 6, No. 7.

Olajuyigbe, A.E., Adegboyega, S.A., Popoola, O.O., and Olalekan, O.A. (2015). Assessment of urban land use and environmental sensitive area degradation in Akure, Nigeria using remote sensing and GIS techniques. European Scientific Journal, Vol. 11, No. 29, pp 22-29 
Petersen, R., D. Askenov, E. Goldman, S. Sargent, N. Harris, A. Manisha, E. Esipova, V. Shevade, and T. Loboda (2016). Mapping tree plantations with multispectral imagery: Preliminary results for seven tropical countries.Technical Note. Washington, DC: World Resources Institute.

Putz FE and Redford KH. (2010). The importance of defining 'forest: Tropical forest degradation, deforestation, long-term phase shifts, and further transitions. Biotropica. 42:10-20.

Reid, R. S., Kruska, R. L., Muthui, N., Taye, A., Wotton, S., Wilson, C. J. and Woudyalew M. (2010). Land-use and land-cover dynamics in response to changes in climatic, biological and socio-political forces: the case of southwestern Ethiopia. Landscape Ecology 15: 339-355.

Shrestha, H.L. (2010). GIS and remote sensing application for resource mapping.https://www.researchgate.net/publication/229046519_GIS_and_Remote_Sen sing Applications for Resource Mapping. Retrieved 2018-10-29

Ståhl G, Cienciala E, Chirici G, Lanz A, Vidal C, Winter S, McRoberts RE, Rondeux J, Schadauer K, Tomppo E. (2012). Bridging national and reference definitions for harmonizing forest statistics. Forest Science. 58:214-223.

Stibig, H.R., R. Beuchle, and F. Achard.(2003). Mapping of the Tropical Forest Cover of Insular Southeast Asia from SPOT4-Vegetation Images.International Journal of Remote Sensing 24:36; 51-62

Tropek R, Sedláček O, Beck J, Keil P, Musilová Z, Šímová I, Storch D. (2014). Comment on "High-resolution global maps of 21st-century forest cover change" Science, 344:981.

Turner, B. L, Moss, R. H., and Skole, D. L. (1993). Relating land use and global land cover change: A proposal for an IGBP-HDP core project. Report from the IGBP-HDP working group on land use/land cover change. Joint Publication of the IGBP No. 24 and HDP No, 5. Swedish Academy of Sciences, Stockholm.

Turner, B. L. and Meyer, B. L. (1994). Global land use and land cover change: An overview. In Meyer, W. B. \&. Turner B. L. II (Eds) Changes in land use and land cover: A global perspective: 3-10. Cambridge University Press.

United Nations Habitat (UN), (2010). Vegetation and nature. www.wikipedia.org/search/.... Assessed 2018-12-03

Upadhyay, M. (2009). Making GIS work in forest management. Institute Of Forestry, Pokhara, Nepal.

Williams, M. (1994). Forest and tree cover. A global perspective. pp 97-124. Cambridge University Press.

Zaitunah, A. (2015). Application of Remote Sensing and Geoinformation in Modeling Forest Management Plan to Support Water. Available at: https://www.researchgate.net/publication/42320167_Application_of_Remote_Sensing/ 